\title{
PENGARUH KEPEMIMPINAN TRANSFORMASIONAL TERHADAP KEPUASAN KERJA KARYAWAN DIMEDIASI OLEH KEADILAN ORGANISASI PADA RSIA CAHAYA BUNDA CIREBON
}

\author{
Oleh : \\ Sylvani \\ Fakultas Ekonomi, Universitas Muhammadiyah Cirebon \\ Sylvanivani19@gmail.com \\ Ali Jufri \\ Fakultas Ekonomi, Universitas Muhammadiyah Cirebon \\ ali.jufri@umc.ac.id \\ Sari Laelatul Qodriah \\ Fakultas Ekonomi, Universitas Muhammadiyah Cirebon \\ sari.lq@umc.ac.id
}

\section{Article Info}

Article History :

Received 02 Feb - 2020

Accepted $20 \mathrm{Feb}-2020$

Available Online 28 Feb - 2020
Keyword:

Transformational Leadership,

Job

Organizational

Hospital.
DOI Artikel : https://doi.org/10.34308/eqien.v7i1.104

\section{Abstract}

Health in the modern era is now an inseparable necessity from the development of healthy and smart Indonesian people. Hospitals as one of the health facilities that provide health services to the community have a very strategic role in accelerating the improvement of community health status. Therefore, hospitals are required to provide quality services in accordance with established standards and can reach all levels of society. For this reason, the need for synergy between leaders and employees. Employees still complain about the way leaders handle each employee's complaints, such as complaints of discrepancies between salaries and work performed, employees still feel discriminated in the sense of being discriminated according to social status, the length of the process of determining to become permanent employees, and so forth. From the factors mentioned above that the role of the leader in leading must be wise and fair both for the organization and employees in the organization. This study aims to obtain empirical evidence of whether or not the influence of transformational leadership on job satisfaction is mediated by organizational justice. This study used a correlational quantitative method and the data processing was assisted with SPSS 22. The population of this study was all employees of RSIA Cahaya Bunda including permanent employees and contract employees while the study sample was only 127 permanent employees. Determination of samples using Slovin formula. The results of this study indicate that transformational leadership has a direct positive effect on job satisfaction, organizational justice has a positive effect on job satisfaction, transformational leadership has a positive effect on organizational justice and organizational justice is able to mediate the relationship between transformational leadership and job satisfaction. 


\section{PENDAHULUAN}

Salah satu sumber daya yang menjadi ujung tombak dari setiap perusahaan adalah karyawan. Faktor tenaga kerja manusia memegang peranan yang sangat penting dalam pencapaian tujuan organisasi. Di dalam perusahaan, karyawan pun berhak memiliki rasa aman dan nyaman dalam melakukan pekerjaannya. Sehingga, akan muncul output yang dinamakan kepuasan kerja. Kepuasan kerja (job satisfaction) merupakan reaksi individu terhadap kondisi pekerjaan dan pengalaman- pengalaman selama bekerja. Kepuasan kerja mempunyai konsekuensi terhadap sikap dan perilaku karyawan, yaitu komitmen dan intensi keluar. Penelitian ini lebih menitikberatkan aspek-aspek kepuasan kerja berdasarkan The Minnesota Satisfaction Questionare (MSQ) (Weiss, Dawis, England \& Lofquist, 1967). Berdasarkan skala tersebut, aspek kepuasan kerja ada tiga yaitu kepuasan kerja secara umum, kepuasan intrinsik, dan kepuasan ekstrinsik. Aspek-aspek tersebut berdasarkan pada tiga rasionalisasi yaitu a) adanya harapan akan lingkungan kerja mereka yang didasarkan pada latar belakang, kemampuan individu, dan minat; b) adanya sikap kerja yang terbentuk dari pemenuhan harapan-harapan di tempatkerja; c) sikap tersebut membentuk evaluasi terhadap lingkungan kerja atau kepuasan kerja mereka (Newby, 1999).

Dalam bekerja seseorang memberikan apa yang ada dalam dirinya kepada organisasi, dan sebaliknya dia juga menuntut supaya organisasi memberikan apa yang menjadi keinginannya. Sumbangan tersebut seperti usaha, keterampilan, loyalitas, kreativitas serta lainnya yang membuat setiap individu sebagai sumber daya bagi organisasi. Hal tersebut membuat organisasi memberikan imbalan kepada karyawan tersebut. Imbalan dapat berupa gaji, fasilitas, status, keamanan kerja, dan sebagainya. Bagi karyawan, imbalan yang diberikan organisasi dapat memuaskan satu atau lebih kebutuhannya. Jika dalam hal tersebut terjadi keadilan, maka terjadilah suatu keseimbangan antara harapan serta kenyataan yang diperoleh. Hal ini akan membuat karyawan terpuaskan dan akan menunjukan hubungan yang positif dengan organisasi yang mengarah pada komitmen. Sedangkan sebaliknya, jika seorang karyawan memandang bahwa organisasinya tidak dapat memenuhi satu atau beberapa hal yang dibutuhkannya atau dengan kata lain terjadi ketidakcocokan antara organisasi dengan karyawan yang membuat karyawan merasa tidak puas, maka akan terjadi proses keluarnya individu (karyawan) dari keanggotaan suatu organisasi. Maka dari itu, di dalam organisasi atau perusahaan terdapat keadilan-keadilan yang dapat mempengaruhi dari komitmen setiap karyawan. Siti Hidayah dan Haryani (2013), menyatakan bahwa konsep keadilan yang dimaksud dalam hubungannya meningkatkan kinerja adalah keadilan organisasi yang mencakup tiga bentuk keadilan, yaitu keadilan distributif, keadilan prosedural, dan keadilan interaksional. Keadilan yang karyawan kenal hanya sebatas penggajian, promosi kebijakan penilaian kinerja dan kebijakan lainnya yang berkaitan dengan kepentingan masing-masing karyawan yang dipusatkan dalam organisasi. Padahal keadilan yang diberikan perusahaan atau instansi tidak hanya mengacu pada keadilan mengenai bagaimana perusahaan memberikan gaji dan promosi untuk karyawan, tetapi juga perusahaan harus mampu memberikan punishment bagi karyawan yang melakukan kesalahan ataupun reward bagi karyawan yang memang memberikan kontribusi lebih terhadap organisasi tanpa harus membeda-bedakan karyawan satu dengan yang lainnya.

Kepuasan kerja yang dimediasi oleh keadilan organisasi tidak akan terlaksana dengan baik tanpa peran pemimpin yang baik dan bijaksana. Peran kepemimpinan dari seorang pemimpin yang baik dan professional serta mutu pelayanan erat hubungannya dengan kualitas SDM yang ada. Suasana organisasi yang kondusif untuk berkarya akan mendorong SDM mengeluarkan potensi yang dimilikinya. Hal ini bisa terjadi bila karyawan mempunyai ikatan emosional dan rasional yang kuat pada organisasi. Munculnya ikatan tersebut sangat bergantung pada gaya kepemimpinan organisasi. Gaya kepemimpinan yang mampu mendorong karyawan mengeluarkan seluruh potensi dengan senang hati adalah transformasional. Terlebih lagi dalam dunia manajemen, khususnya manajemen sumber daya manusia, tentu pemimpin dan kepemimpinan saling berkaitan agar manajemen yang dijalankan tercipta hasil dengan baik. Salah satu contoh seorang pemimpin yang menerapkan kepemimpinan transformasional adalah Bill Gates. Bill Gates merupakan pendiri perusahaan Microsoft yang hingga saat ini masih menjadi sebuah perusahaan yang terbesar di dunia. Gaya kepemimpinan Bill Gates, yaitu berpikir 
kedepan, Tetap fokus, Berpikir besar, Hasrat, Selalu belajar, Peduli terhadap sesama.

Diatas telah dipaparkan contoh pemimpin dunia yang memiliki kepemimpinan transformasional. Bahwa keahlian, motivasi serta ajakan untuk merangkul bersama dapat meningkatkan semangat pengikut yang disini dikonstentrasikan sebagai karyawan atau pegawai. Dari banyaknya industri-industri yang ada di Indonesia, tepatnya di wilayah Cirebon, peneliti lebih menitik beratkan pada rumah sakit. Seperti halnya industri rumah sakit saat ini, Rumah sakit sebagai salah satu sarana kesehatan yang memberikan pelayanan kesehatan kepada masyarakat memiliki peran yang sangat strategis dalam mempercepat peningkatan derajat kesehatan masyarakat. Oleh karena itu, rumah sakit dituntut untuk memberikan pelayanan yang bermutu sesuai dengan standar yang ditetapkan dan dapat menjangkau seluruh lapisan masyarakat. Di Cirebon, salah satu rumah sakit yang terkenal dengan brand image pelayanan terbaik adalah Rumah Sakit Ibu dan Anak Cahaya Bunda. Rumah Sakit Ibu dan Anak Cahaya Bunda diresmikan oleh walikota Cirebon (Alm) Drs. Ano Sutrisno, MM pada tanggal 11 November 2014. Sebagai bentuk kepedulian kesehatan masyarakat, RSIA Cahaya Bunda berkomitmen penuh dalam mewujudkan yang sehat dan bebas dari penyakit serta menurunkan angka kematian ibu dan anak maka didirikanlah rumah sakit ibu dan bayi. Dengan berkembangnya penduduk di kota Cirebon semakin pesat dan semakin berkembangnya kebutuhan pelayanan kesehatan ibu dan anak. Maka didirikanlah Rumah Sakit ibu dan anak untuk melayani kebutuhan kesehatan ibu dan anak. RSIA Cahaya Bunda memiliki badan hukum PT. Cipta Hasil Yasmin dengan Direktur dijabat oleh dr. Yasmin Dermawan, Sp.OG dan saat ini, Direktur RSIA Cahaya Bunda dijabat oleh dr. H. Erwin Didi Purnama, MM.Rs.

Kepemimpinan yang paling berpengaruh disini adalah kepemimpinan dari pemilik rumah sakit RSIA Cahaya Bunda yaitu dr. Yasmin Dermawan, Sp.OG dikarenakan beliau adalah pemimpin tertinggi diatas Direktur RSIA Cahaya Bunda dr. H. Erwin Didi Purnama, MM.Rs., sisi kepemimpinan dr. Yasmin Dermawan, Sp.OG yaitu dimunculkan dengan beliau selalau memotivasi setiap karyawan untuk bekerja dengan baik dan sesuai target, keahlian dalam memimpin organisasi sangat dipercaya oleh karyawan RSIA Cahaya Bunda serta memiliki wibawa dan charisma yang dijadikan panutan oleh para karyawan RSIA Cahaya Bunda.

Fenomena yang mendasari dari penelitian ini adalah seperti yang telah dipaparkan diatas bahwa kepemimpinan transformasional sudah dijalankan tetapi masih dirasa belum maksimal seperti masih banyak ketidakpuasan pelanggan/pasien dalam mendapatkan pelayan dari pihak rumah sakit baik oleh tenaga medis maupun non-medisnya. Dilihat dari data rekapitulasi September s.d. oktober 2016 persentase ketidakpuasan pelanggan yaitu, Pelayanan : 51,7 \%, SDM : 14,2 \%, Sarana \& Prasarana : $33,9 \%$. Untuk Pelayanan, tingkat complain/ketidakpuasan pasien terjadi pada proses pendaftaran pasien, pembayaran atau administrasi di Kasir, pelayanan di Apotik, pelayanan di Poliklinik dan Rawat Inap, Petugas Gizi, Petugas Kebersihan. Untuk SDM, tingkat complain/ketidakpuasan pasien seperti pada sikap petugas yang kurang care dan komuniikatif, lebih professional, dan keramahan petugas. Untuk Sarana \& Prasarana, tingkat complain/ketidakpuasan pasien tebanyak pada keterbatasan lahan parkir, Tidak dinginnya AC khususnya di area Poliklinik, kurangnyajumlah kamar mandi dan ruang tunggu yang tidak terlalu luas di poliklinik, ruang menyusui di lt. 1 yang tidak menggunakan $\mathrm{AC}$, serta tingkat kebersihan di kamar mandi ruang rawat inap.

Ini berarti menandakan adanya ketidaksesuaian karyawan dalam melaksanakan pekerjaannya padahal aturan sudah dibuat sebagaimana mestinya. Selain itu, tunjangantunjangan yang di dapat oleh setiap karyawan hanya didapat oleh karyawan tetap saja sesuai dengan tingkat jabatan masing- masing, tidak melihat apakah seseorang itu bekerja secara rajin atau tidak. Karyawan yang sudah bekerja dengan keras masih belum merasa adanya kepuasan di dalam bekerja. Tentu ini menjadi muncul awalnya ketidakpuasan karyawan dalam bekerja mulai dari berkurangnya kedisplinan yaitu dalam 1 minggu, 9 atau 10 karyawan sering datang terlambat terlihat dari data absen sejak bulan November 2018, lalu dilihat dari data keluarmasuknya karyawan sejak bulan Mei 2018 yaitu 31 karyawan yang mengundurkan diri dari Rumah Sakit, sebagian dari lini pelayanan medis. Selain itu, karyawan masih mengeluhkan cara pemimpin menangani setiap keluhan para karyawan, seperti keluhan ketidaksesuaian antara gaji dengan pekerjaan yang dilakukan, 
karyawan masih merasa dibeda-bedakan dalam arti masih dibeda-bedakan sesuai status sosial, lamanya proses penetapan menjadi karyawan tetap, dan lain sebagainya. Dari faktor-faktor yang disebutkan diatas bahwa peran pemimpin dalam memimpin harus bijak dan adil baik untuk organisasi maupun karyawan didalam organisasi tersebut.

\section{KERANGKA PEMIKIRAN PENGEMBANGAN HIPOTESIS \\ Kepemimpinan}

Kepemimpinan merupakan salah satu fungsi manajemen yang sangat penting dalam upaya pencapaian tujuan. Kepemimpinan merupakan kegiatan pemimpin dalam hal mempengaruhi, mendorong dan membimbing serta mengarahkan kegiatan orang lain agar mampu menerima pengaruh itu dan selanjutnya dapat membantu pencapaian tujuan yang telah ditetapkan oleh perusahaan. Pengertian kepemimpinan secara luas menurut Richard L. Draft (dalam Irham Fahmi, 2011:15) adalah "Kepemimpinan (leadership) adalahkemampuan memengaruhi orang yang mengarah kepada pencapaian tujuan". Pendapat ini menekankan bahwa kepemimpinan adalah proses untuk memengaruhi karyawan (pengikut) atau sekelompok orang (termasuk perilaku/ budayanya) agar dapat berubah sesuai dengan keinginan organisasi dalam upaya mencapai tujuan yang ditetapkan. Menurut Roach \& Behling (dalam Sarlito W.S; 2005:39) kepemimpinan didefinisikan sebagai "Proses memengaruhi aktivitas sebuah kelompok yang terorganisasi menuju pencapaian suatu tujuan". Dari pendapat ini tampak bahwa kepemimpinan sebagai suatu proses yang melibatkan pimpinan, yang dipimpin (bawahan) dan situasi. Robbins (dalam Irham Fahmi, 2011: 15) mendefinisikan kepemimpinan sebagai "Kemampuan untuk memengaruhi suatu kelompok ke arah tercapainya tujuan".

\section{Kepemimpinan Transformasional}

Kepemimpinan

transformasional mengasumsikan bahwa pemimpin menciptakan visi dan lingkungan yang memotivasi para karyawan untuk berprestasi melampaui harapan. Model kepemimpinan transformasional merupakan model yang relatif baru dalam studistudi kepemimpinan. Konsep kepemimpinan transformasional mengintegrasikan ide-ide yang dikembangkan dalam pendekatan watak, gaya dan kontingensi. Kebanyakan teori terbaru dari kepemimpinan transformasional amat terpengaruhi oleh Burns (1978). Menurut Burns (dalam Yukl 2010:290) Kepemimpinan transformasional menyerukan nilai-nilai moral dari pada pengikut dalam upayanya untuk meningkatkan kesadaran mereka tentang masalah etis dan untuk memobilisasi energi dan sumber daya mereka untuk mereformasi institusi. Menurut Bass (dalam Yukl, 1996:224) bahwa kepemimpinan transformasional sebagai pemimpin yang mempunyai kekuatan untuk mempengaruhi bawahan dengan cara-cara tertentu. Yukl (2009:315) menyatakan bahwa kepemimpinan transformasional sering didefinisikan melalui dampaknya terhadap bagaimana pemimpin memperkuat sikap saling kerjasama dan mempercayai, kemanjuran diri secara kolektif, dan pembelajaran tim. Pada Kepemimpinan Transformasional, keseganan itu tercapai karena azas dan pola pikir sang pemimpin yang dianggap benar dan rasional. Pada pola Kepemimpinan Transformasional, pergantian pemimpin lebih mudah diterima oleh para pengikut apabila pemimpin baru juga memiliki cara berpikir serta ciri memimpin yang sama dengan pemimpin lama. Kepemimpinan Transformasional lebih banyak digunakan pada manajemen modern.Sedangkan, kepemimpinan Karismatis pada era modern masih banyak ditemukan pada organisasi-organisasi keagamaan, manajemen tradisional, lembaga kemasyarakatan, pemerintahan, dan manajemen pada perusahaan keluarga.

\section{Kepuasan Kerja}

Pembahasan mengenai kepuasan kerja perlu diketahui oleh penegasan bahwa masalah kepuasan kerja bukanlah hal yang sederhana baik dalam arti konsepnya maupun arti analisisnya, karena "kepuasan" mempunyai konotasi yang beraneka ragam. Kepuasan kerja (job satisfaction) adalah keadaan emosional yang menyenangkan atau tidak menyenangkan dengan mana para karyawan memandang pekerjaan mereka. Kepuasan kerja mencerminkan perasaan seseorang terhadap pekerjaannya. Karena tidak sederhana, banyak faktor yang perlu mendapat perhatian dalam menganalisis kepuasan kerja seseorang. Misalnya, sifat pekerjaan seseorang mempunyai dampak tertentu pada kepuasan kerjanya. Berbagai penelitian telah membuktikan bahwa apabila dalam pekerjaaanya seseorang mempunyai otonomi untuk bertindak, terdapat variasi, memberikan sumbangan penting dalam tentang hasil pekerjaan yang dilakukannya, yang bersangkutan akan merasa puas. Bentuk 
program perkenalan yang tepat serta berakibat pada diterimanya seseorang sebagai anggota kelompok kerja dan oleh organisasi secara ikhlas dan terhormat juga pada umumnya berakibat pada tingkat kepuasan kerja yang tinggi.Situasi lingkungan pun turut berpengaruh pada tingkat kepuasan kerja seseorang. Sehingga kepuasan kerja adalah perasaan yang menyeluruh tentang pekerjaan atau sebuah hubungan konstalasi sikap seseorang pada berbagai aspek pekerjaan (Spector, 1997). Kepuasan kerja berhubungan dengan sikap dan penilaian karyawan pada pekerjannya. Kepuasan kerja adalah representasi dari kesukaan atau ketidaksukaan karyawan dalam melihat pekerjaannya. Hal ini diperkuat oleh Luthans (1995) dan Handoko (1993) yang menyatakan bahwa kepuasan kerja merupakan hasil persepsi karyawan tentang bagaimana suatu pekerjaan dapat memberikan sesuatu yang dianggap penting. Persepsi karyawan tersebut dapat menimbulkan efek negatif maupun positif terhadap pekerjaannya.Untuk memahami lebih rinci tentang kepuasan kerja, maka konsep tersebut harus dijelaskan melalui aspek-aspek pendukungnya. Aspek-aspek dari kepuasan kerja antara lain jaminan pekerjaan (job security), gaji dan kompensasi lainnya, rekan kerja (sosial satisfaction), supervisi, dan kesempatan untuk berkembang secara individu (growth and development) (Hackman \& Oldham, 1975). Ahli lain (Spector, 1997) menambah aspek kepuasan kerja tersebut dengan hal-hal sebagai berikut: kondisi kerja, adanya penghargaan, sifat pekerjaan, dan adanya komunikasi yang harmonis. Sebetulnya aspek-aspek itu akan menjadi lebih mudah dipahami bila konsep itu dikategorikan menjadi dua yaitu aspek yang menimbulkan rasa puas dan aspek yang menyebabkan ketidakpuasan. Hal-hal yang memunculkan rasa puas yaitu prestasi kerja, penghargaan, kenaikan jabatan dan pujian. Halhal yang menyebabkan ketidakpuasaan adalah kebijaksaan perusahaan, supervisor, kondisi rekan kerja dan gaji.

\section{a. Keadilan Organisasi}

Sejarah keadilan organisasional berawal dari teori keadilan (Adams, 1963). Teori ini menyatakan bahwa orang membandingkan rasio antara hasil dari pekerjaan yang merekalakukan, misalnya imbalan dan promosi, dengan input yang mereka berikan dibandingkan rasio yang sama dari orang lain. Greenberg (1990) selanjutnya menjelaskan bahwa teori keadilan Adams dilengkapi dengan riset-riset lanjutan yang terkait dengan alokasi imbalan, merujuk pada konsep yang dikenal sekarang sebagai keadilan distributif. Robbins dan Judge (2008) mendefinisikan keadilan distributif sebagai keadilan jumlah dan penghargaan yangdirasakan diantara individu-individu. Keadilan organisasi adalah penilaian karyawan terhadap seberapa adil atau layak perlakuan organisasi terhadap dirinya (Widyaningrum, 2010). Cropanzano et al., (2001) menyatakan bahwa terdapat tiga alasan mengapa karyawan peduli terhadap masalah keadilan organisasi. Pertama, manfaat jangka panjang, karyawan lebih memilih keadilan yang konsisten daripada hanya terbatas dari keputusan seseorang, karena dengan adanya keadilan tersebut karyawan dapat memprediksi hasil di masa yang akan datang. Karyawan juga mau menerima imbalan yang tidak menguntungkan sepanjang proses pembayarannya adil dan mendapat perlakuan yang bermartabat. Kedua, pertimbangan sosial, setiap orang mengharapkan diterima dan dihargai oleh pemimpin tidak dengan cara kasar dan tidak dieksploitasi. Ketiga, pertimbangan etis, orang percaya bahwa keadilan merupakan cara yang secara moral tepat dalam memperlakukan seseorang.

\section{Kerangka Pemikiran}

Kerangka berfikir merupakan konsep awal yang menjadi acuan dalam sebuah penelitian. Kerangka pemikiran teoritis memiliki dasardasar dari sumber penelitian terdahulu yang relevan dan mendukung pelaksanaan sebuah penelitian yang ingin dilakukan. Dalam konteks yang lebih sederhana, kerangka berfikir menjadi gambaran sebuah penelitian yang ditunjukan oleh variabel-variabel yang saling berhubungan satu sama lain dan landasan sebuah penelitian. Pada penelitian ini dilakukan pengukuran pengaruh variabel independen, yaitu gaya kepemimpinan transformasional (X1), Kepuasan Kerja (Y) dimediasi oleh Keadilan Organisasi (Z).

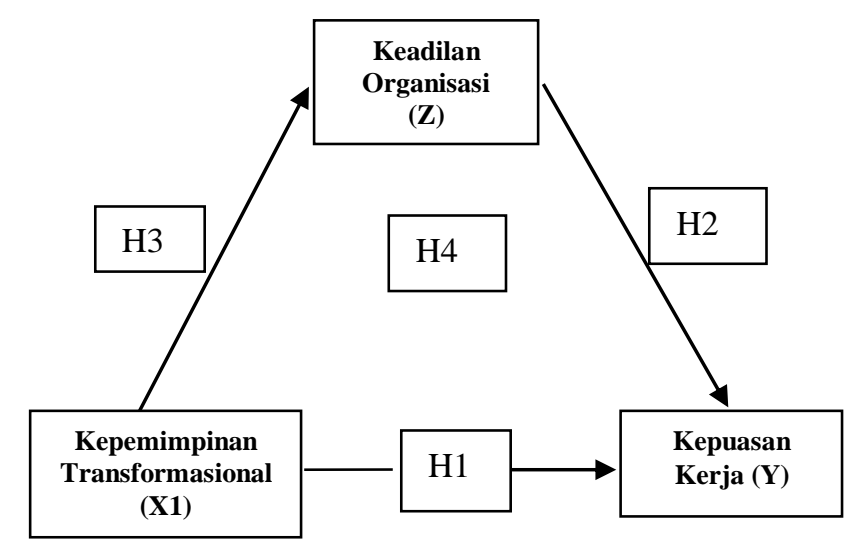




\section{Gambar 1 Kerangka Pemikiran}

\section{METODE PENELITIAN}

\section{Metode Pengumpulan Data}

Metode pengumpulan data dalam penelitian merupakan metode atau cara yang digunakan untuk mendapatkan data dalam suatu penelitian. Metode pengumpulan data dalam penelitian ini menggunakan Metode Kuesioner. Kuesioner adalah sejumlah pertanyaan secara tertulis yang akan dijawab oleh responden penelitian, agar peneliti memperoleh data lapangan/empiris untuk memecahkan masalah penelitian dan menguji hipotesis yang telah ditetapkan. Dalam penelitian ini, kuesioner yang digunakan adalah kuesioner tertutup yaitu model pertanyaan dimana pertanyaan tersebut telah tersedia jawaban, sehingga responden hanya memilih dari alternatif jawaban yang sesuai dengan pendapat atau pilihannya. Pertanyaan-pertanyaan tertutup tersebut menerangkan tanggapan responden terhadap variabel gaya kepemimpinan transformasional, kepuasan kerja dan keadilan organisasi.

\section{Populasi dan Sampel}

Populasi didefinisikan sebagai keseluruhan subyek penelitian (Arikunto, 1998). Dalam penelitian ini yang menjadi populasi adalah Seluruh karyawan Rumah Sakit Ibu dan Anak Cahaya Bunda Kota Cirebon berjumlah 210 karyawan terdiri dari 187 karyawan tetap dan 23 karyawan kontrak. Namun karyawan yang menjadi subjek penelitian ini adalah karyawan tetap, bukan karyawan kontrak maupun honorer. Metode untuk menentukan jumlah sampel yang akan diteliti menggunakan rumus slovin, yaitu :

$$
\mathrm{n}=\frac{\mathrm{N}}{1+\mathrm{Ne} 2}
$$

Keterangan :

$\mathrm{n}=$ Jumlah sampel minimal

$\mathrm{N}=$ Jumlah populasi

$\mathrm{e}=$ Presentase kelonggaran ketelitian karena

kesalahan

Berdasarkan rumus diatas jumlah sampel yang diambil adalah :

$$
\begin{aligned}
& \mathrm{n}=\frac{187}{1+(187)(0.05)^{2}} \\
& =\frac{187}{1+(1870)(.0025)} \\
& =\frac{187}{1,4675} \\
& =127
\end{aligned}
$$

Jadi jumlah sampel dalam penelitian ini adalah 127 responden.

\section{HASIL DAN PEMBAHASAN \\ Hasil dan Pembahasan \\ Pengaruh Kepemimpinan Transformasional Terhadap Kepuasan Kerja}

Pengujian hipotesis pertama menunjukan nilai koefisien kolerasi 0,445 dan nilai t hitung sebesar 5,554 menunjukan lebih besar dari t tabel sebesar 1,984, dengan signifikansi 0,000 hal ini berarti bahwa pengaruh yang terjadi pada variabel kepemimpinan terhadap variabel kepuasan kerja berpengaruh positif dan signifikan, sehingga hipotesis pertama dapat diterima.

Kepemimpinan transformasional adalah kepemimpinan yang peka terhadap perubahan yang terjadi di lingkungan sekitar serta mampu untuk melakukan perubahan ke arah pengembangan organisasi. Kepemimpinan transformasional dalam organisasi merupakan penggambaran langkah kerja bagi karyawan yang berada di bawahnya. Gaya kepemimpinan transformasional mengandung arti cara pemimpin memengaruhi bawahan untuk lebih dapat berbuat atau berusaha dalam rangka mencapai tujuan organisasi. Seorang pemimpin atau manajer dalam mengarahkan dan menggerakkan bawahannya untuk mencapai tujuan yang direncanakan merupakan hal yang penting dalam suatu organisasi. Purnomo (2010) menyatakan bahwa kepemimpinan transformasional berpengaruh terhadap kepuasan kerja karyawan karena tipe kepemimpinan ini mampu memotivasi karyawannya. Menurut Avolio, Bass, dan Jung (1999) kepemimpinan transformasional merupakan perilaku pemimpin yang dapat mengaktifkan motivasi pengikutnya serta mendorong mereka bertindak atas motivasi tersebut demi kinerja yang tinggi. Konsep kepemimpinan yang diuraikan oleh Bass dan Avolio (1999) diuraikan lebih lanjut dalam bentuk indikator oleh Xiragar (2008) dimana gaya kepemimpinan transformasional meliputi Idealized influence, Inspirational motivation, Intelectual stimulation, Individualized consideration. Kepemimpinan transformasional akan membuat para pengikut merasakan kepercayaan, kekaguman, kesetiaan dan penghormatan terhadap pemimpin, dan 
mereka termotivasi untuk melakukan lebih dari pada yang awalnya diharapkan dari mereka (Yulk, 2010).

Yunita (2008) menyatakan kepemimpinan transformasional menciptakan visi organisasi yang dinamis sehingga menciptakan suatu inovasi. Pemimpin dalam melakukan tugas kepemimpinannya selalu dapat memperhatikan aspirasi dan juga dapat mengatur tugas-tugas yang harus diperhatikan dengan baik, akan dapat menimbulkan suatu perasaan senang pada karyawan terhadap pemimpin tersebut sehingga mampu menciptakan kepuasan kerja. Oleh karena itu, gaya kepemimpinan seorang pemimpin juga merupakan hal yang penting dalam meningkatkan kepuasan yang ada pada karyawan.

\section{Pengaruh Keadilan Organisasi Terhadap Kepuasan Kerja Karyawan}

Pengujian hipotesis kedua menunjukan nilai koefisien kolerasi 0,714 dan nilai $\mathrm{t}$ hitung sebesar 11,393 menunjukan lebih besar dari $\mathrm{t}$ tabel sebesar 1,984, dengan signifikansi 0,000 hal ini berarti bahwa pengaruh yang terjadi pada variabel keadilan organisasi terhadap kepuasan kerja berpengaruh positif dan signifikan, sehingga hipotesis kedua dapat diterima.

Karyawan tentu saja menuntut kesejahteraan, tetapi sebenarnya yang mereka perlukan lebih dari itu. Pada konteks etis inilah, tema keadilan organisasional menjadi penting. Keadilan organisasional telah dibuktikan menjadi anteseden bagi sikap dan perilaku karyawan. Tentunya ketika keadilan organisasi seimbang, maka muncullah kepuasan kerja yang dapat dirasakan oleh setiap karyawan. Hanya saja, karyawan merasa ada bagian ketidakadilan dibagian pengangkatan karyawan tetap.Salah satu sikap karyawan yang banyak menjadi bahan penelitian dihubungkan dengan keadilan organisasional adalah kepuasan kerja. Dalam dunia yang kompetitif, tantangan terbesar yang dihadapi oleh perusahaan adalah bagaimana mempertahankan karyawan yang kompeten. Kepuasan kerja diperlukan untuk menghasilkan perilaku karyawan yang fungsional di perusahaan. Bagi perusahaan, kepuasan kerja karyawannya berarti mereka termotivasi dan berkomitmen untuk mencapai kinerja yang tinggi. Seperti dalam banyak riset yang dilakukan, konsekuensi yang diperoleh dari pengelolaan keadilan organisasional adalah kepuasan kerja. Riset-riset tersebut antara lain dilakukan oleh Cohen-Carash dan Spector (2001), Mossholder et al. (1998), Masterson et al. (2000), dan McFarlin dan Sweeney (1992). Ketiga dimensi keadilan organisasional, yaitu distributif, prosedural, dan interaksional telah ditemukan berpengaruh secara positif dan signifikan terhadap kepuasan kerja.

\section{Pengaruh Kepemimpinan Transformasional Terhadap Keadilan Organisasi}

Pengujian hipotesis ketiga menunjukan nilai koefisien kolerasi 0,462 dan nilai $t$ hitung sebesar 5,821 menunjukan lebih besar dari $t$ tabel sebesar 1,984, dengan signifikansi 0,000 hal ini berarti bahwa pengaruh yang terjadi pada variabel kepemimpinan transformasional terhadap variabel keadilan organisasi berpengaruh positif dan signifikan, sehingga hipotesis ketiga dapat diterima. Memang, meskipun kepemimpinan transformasional memiliki efek tidak langsung pada sinisme melalui keadilan interaksional (Wu et al., 2007), tidak ada penelitian sebelumnya dari hubungan antara kepemimpinan transformasional, keadilan organisasi, dan QWL. Namun, pemimpin transformasional menampilkan praktik yang adil dalam interaksi sehari-hari mereka dengan bawahan (Greenberg, 2004). Selain itu, keadilan organisasi adalah salah satu proses kunci untuk hubungan positif antara kepemimpinan transformasional dan hasil yang menguntungkan (lihat van Knippenberg et al., 2004; Naumann dan Bennett, 2000).

Kepemimpinan merupakan salah satu faktor penentu keberhasilan organisasi. Begitu pula pada kepemimpinan transformasional, bisa menjadi faktor keadilan yang dapat dirasakan karyawan. Karyawan mengakui adanya kepemimpinan transformasional, tetapi dari sisi keadilan organisasi masih sedikit kurang memenuhi harapan setiap karyawan. Masih adanya kekurangan antara gaji dengan pekerjaan yang dilakukan, merasa ada pengelompokan untuk orang-orang tertentu serta ketidaksesuaian perintah yang jelas.

\section{Pengaruh Keadilan Organisasi Sebagai Mediasi Hubungan Kepemimpinan Transformasional Terhadap Kepuasan Kerja}

Hasil Uji t dilakukan sebanyak dua kali dikarenakan untuk mengetahui ada atau tidaknya pengaruh keadilan organisasi sebagai variabel mediasi. Pengujian hipotesis pertama pada uji hipotesis keempat menunjukan kepemimpinan transformasional terhadap keadilan organisasi 
nilai koefisien kolerasi 0,462 dan nilai t hitung sebesar 5,821 menunjukan lebih besar dari $\mathrm{t}$ tabel sebesar 1,984, dengan signifikansi 0,000 hal ini berarti bahwa pengaruh yang terjadi pada variabel kepemimpinan transformasional terhadap variabel keadilan organisasi berpengaruh positif dan signifikan, sehingga hipotesis keempat dapat diterima.

Pengujian hipotesis kedua pada uji hipotesis keempat menunjukan keadilan organisasi terhadap kepuasan kerja nilai koefisien kolerasi 0,714 dan nilai $t$ hitung sebesar 11,393 menunjukan lebih besar dari t tabel sebesar 1,984, dengan signifikansi 0,000 hal ini berarti bahwa pengaruh yang terjadi pada variabel keadilan organisasi terhadap variabel kepuasan kerja berpengaruh positif dan signifikan, sehingga hipotesis keempat dapat diterima.

Selanjutnya hipotesis IV dilakukan analisis regresi sebanyak dua kali, regresi pertama dilakukan antara kepemimpinan transformasional terhadap keadilan organisasi. Regresi kedua dilakukan antara keadilan organisasi terhadap kepuasan kerja. Hasil regresi menunjukan bahwa nilai koefisien regresi kepemimpinan transformasional terhadap keadilan organisasi sebesar 0,322 dengan standar error 0,055 dengan nilai sginifikansi 0,000 kemudian untuk keadilan organisasi terhadap kepuasan kerja menunjukan bahwa nlai koefisien regresi sebesar 1,034 dengan satndar error 0,091 dengan nilai signifikansi 0,000. Sehingga kepemimpinan transformasional berpengaruh langsung terhadap keadilan organisasi demikian juga keadilan organisasi berpengaruh langsung terhadap kepuasan kerja. Jika digambarkan akan membentuk model :

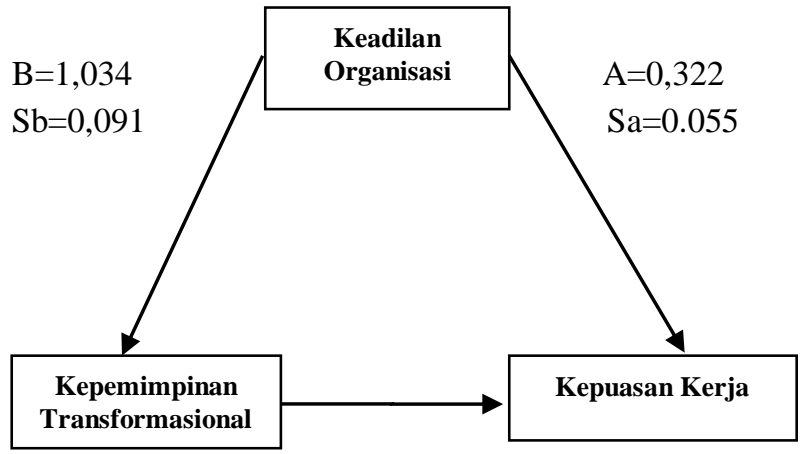

\section{Gambar 2 Hasil Perhitungan}

Model diatas merupakan model yang terbentuk dari regresi pertama dan kedua sehingga membentuk model analisis jalur (path analysis) dengan variabel keadilan organisasi sebagai mediatornya.

Hasil perhitungan dengan rumus sobel test sebesar $\mathrm{Z}=3,549$, karena nilai $\mathrm{Z}$ yang diperoleh sebesar $3,459>1,98$ dengan tingkat signifikansi 5\% maka membuktikan bahwa keadilan organisasi mampu memediasi hubungan kepemimpinan transformasional terhadap kepuasan kerja.

Kepemimpinan transformasional sebagai pengaruh pemimpin atau atasan terhadap bawahan, dimana bawahan merasakan kepercayaan, kebanggaan, loyalitas dan rasa hormat kepada atasan dan mereka dimotivasi untuk berbuat melebihi apa yang ditargetkan atau diharapkan. Gaya kepemimpinan transformasional memiliki pengaruh yang signifikan pada sikap dan perilaku karyawan terhadap pekerjaannya. Pemimpin yang transformasional berkaitan dengan indikator efektivitas kepemimpinan, seperti kepuasan, motivasi, dan kinerja dari karyawan (Bass \& Riggio, 2006). Pemimpin transformasional mampu merumuskan dan mengartikulasikan tujuan ideal organisasi. Hal ini berfungsi sebagai pemberian energi positif serta menciptakan rasa pemberdayaan kepada karyawan. Karyawan mampu menginternalisasikan tujuan tersebut (Castro 2008). Sebagaimana yang diamati Burke (Castro et al., 2008), pemimpin yang memberdayakan bawahan dengan memberikan kejelasan arah dan menekankan tujuan yang lebih tinggi, maka karyawannya akan merasakankepuasan kerja dan semakin berkomitmen terhadap organisasi (Conger \& Kanungo, 1988). Pemimpin dengan kepemimpinannya tentu harus berlaku adil terhadap karyawan.Menurut Greenberg (1990a, 1990b), pada prinsipnya konsep keadilan organisasional didasarkan pada persepsi keadilan dalam pengaturan organisasi. Persepsi karyawan terhadap keadilan organisasional tersebut didefinisikan sebagai evaluasi individu apakah organisasi tempat karyawan bekerja telah memperlakukan anggotanya secara adil atau tidak adil.

\section{KESIMPULAN DAN SARAN}

Berdasarkan hasil penelitian dan pembahasan, maka dapat ditarik kesimpulan sebagai berikut :

1) Terdapat pengaruh langsung kepemimpinan transformasional terhadap kepuasan kerja karyawan RSIA Cahaya Bunda. Hal ini dapat dibuktikan dengan nilai koefisien 
kolerasi 0,445 dan nilai $\mathrm{t}$ hitung sebesar 5,554 menunjukan lebih besar dari $t$ tabel sebesar 1,984, dengan signifikansi 0,000 hal ini berarti bahwa pengaruh yang terjadi pada kedua variabel positif dan signifikan.

2) Terdapat pengaruh keadilan organisasi terhadap kepuasan kerja karyawan RSIA Cahaya Bunda. Hal ini dapat dibuktikan dengan nilai koefisien kolerasi 0,714 dan nilai t hitung sebesar 11,393 menunjukan lebih besar dari $t$ tabel sebesar 1,984, dengan signifikansi 0,000 hal ini berarti bahwa pengaruh yang terjadi pada kedua variabel positif dan signifikan.

3) Terdapat pengaruh kepemimpinan transformsional terhadap keadilan organisasi bagi karyawan RSIA Cahaya Bunda. Hal ini dapat dibuktikan dengan nilai koefisien kolerasi 0,462 dan nilai t hitung sebesar 5,821 menunjukan lebih besar dari t tabel sebesar 1,984, dengan signifikansi 0,000 . Hal ini berarti bahwa pengaruh yang terjadi pada kedua variabel positif dan signifikan.

4) Terdapat pengaruh keadilan organisasi sebagai mediasi hubungan kepemimpinan transformasional dengan kepuasan kerja karyawan RSIA Cahaya Bunda. Hal ini dapat dibuktikan dengan pengujian hipotesis pertama pada uji hipotesis keempat menunjukan kepemimpianan transformasional terhadap keadilan organisasi nilai koefisien kolerasi 0,462 dan nilai $\mathrm{t}$ hitung sebesar 5,821 menunjukan lebih besar dari $t$ tabel sebesar 1,984, dengan signifikansi 0,000 hal ini berarti bahwa pengaruh yang terjadi pada kedua variabel positif dan signifikan. Kemudian pengujian hipotesis kedua pada uji hipotesis keempat menunjukan keadilan organisasi terhadap kepuasan kerjanilai koefisien kolerasi 0,714 dan nilai $t$ hitung sebesar 11,393 menunjukan lebih besar dari t tabel sebesar 1,984, dengan signifikansi 0,000 hal ini berarti bahwa pengaruh yang terjadi pada kedua variabel positif tetapi dan signifikan. Selain itu, untuk menguji keadilan organisasi mampu memediasi atau tidak, peneliti menggunakan sobel test sehingga menghasilkan perhitungan sobel test mendapatkan nilai $\mathrm{Z}$ sebesar 3,549, karena nilai $\mathrm{Z}$ yang diperoleh sebesar 3,459 $>1,98$ dengan tingkat signifikansi 5\% maka membuktikan bahwa keadilan organisasi mampu memediasi hubungan kepemimpinan transformasional terhadap kepuasan kerja.
5) Keadilan organisasi mampu memediasi hubungan antara kepemimpinan transformasional dengan kepuasan kerja dikarenakan karwayan mampu merasakan kepuasan kerja yang diberikan oleh seorang pemimpin melalui sebuah keadilan. Sebaliknya, jika karyawan tidak mampu meraskaan keadilan di dalam organisasi maka karyawan merasa bahwa kepemimpinan dari pemimpinnya sangat jauh dari keinginan sehingga tidak akan terciptanya kepuasan kerja.

6) Pengaruh kepemimpinan transformasional terhadap kepuasan kerja yang dimediasi oleh keadilan organisasi berpengaruh positif di dalam organisasi di RSIA Cahaya Bunda.

\section{REFERENSI}

Siagian, Sondang. P. (2015) manajemen sumber daya manusia, Jakarta: Bumi aksara, 2015

Palupi, Majang, Heru Kurnianto Tjahjono dan Rafika Nuri (2014). "Pengaruh keadilan distributif karir dan keadilan prosedural karir terhadap perilaku retaliasi karyawan swasta di daerah istimewa yogyakarta (diy) dengan kepuasan karir sebagai variabel pemediasian". Jurnal Universitas Paramedina

Krisnayanti, Gusti Ayu, I Gede Riana (2015) "Pengaruh keadilan organisasional terhadap kepuasan kerja karyawan”. EJurnal Manajemen Unud. Univesitas Udayana.

Kristanto, Sentot, I Ketut Rahyuda dan I Gede Riana (2014). "Pengaruh keadilan organisasional terhadap kepuasan kerja dan dampaknya terhadap komitmen, dan intensi keluar di pt indonesia power ubp bali". E- Jurnal Ekonomi dan Bisnis Universitas Udayana. Universitas Udayana.

Kadek Sintha Dewi. 2013. "Pengaruh gaya kepemimpinan transformasional terhadap kepuasan kerja karyawan dan komitmen organisasi pada PT. KPM". Jurnal Manajemen, Strategi Bisnis, dan Kewirausahaan. Universitas Udayana.

Awamleh, R., Mahate, A. \& Evans, J. (2005). "A Test of Transformational and Transactional Leadership Styles on Employees' Satisfaction and Performance in the UAE Banking 
Sector." Journal of Comparative International Management, 8 (1), 3-19.

M. Umer Paracha, Adnan Oamar, Anam Mirza, Inam-ulHasan, Hamid Waqas. (2012). "Impact of Leadership Style (Transformational \& Transactional Leadership) On Employee Performance \& Mediating Role of Job Satisfaction" Study of Private School (Educator) In Pakistan". Global Journals Inc. (USA). University Utara Malaysia.

Sukrajap, Muhammad Ali. (2016). "Pengaruh kepemimpinan transformasional terhadap kepuasan kerja dan komitmen organisasional dengan dimediasi oleh pemberdayaan psikologis". Jurnal Psikologi. Universitas Proklamasi 45 Yogyakarta.

Asgari, Ali, Abu Daud Silong, Aminah Ahmad, Bahaman Abu Samah. (2008). "The Relationship between Transformational Leadership Behaviors, Organizational Justice, Leader-Member Exchange, Perceived Organizational Support, Trust in Management and Organizational Citizenship Behaviors". European Journal of Scientific Research. Universiti Putra Malaysia.

Lale Gumusluoglu, Zahide KarakitapoğluAygün, Giles Hirst. (2012). "Transformational leadership and $R \& D$ workers' multiple commitments: Do justice and span of control matter?". Journal of Business Research. Turkey.

Ömer Faruk İşcana , Göknur Ersarıb , Atılhan Naktiyokc, a. (2014). "Effect of Leadership Style on Perceived Organizational Performance and Innovation : The Role of Transformational Leadership beyond the Impact of Transactional Leadership -An Application among Turkish SME's-". 10th International Strategic Management Conference. Turkey.

Tjahjono, Heru Kurnianto. (2015). "Studi Literatur Pengaruh Keadilan Distributif dan Keadilan Prosedural Pada Konsekuensinya Dengan Teknik Meta Analisis". Jurnal psikologi. Universitas Gadjah Mada.

Ristawati, Agustina. (2013). "Pengaruh Kepemimpinan Transformasional Dan Budaya Organisasi Terhadap Kepuasan Kerja Dan Kinerja Karyawan PT.
Jamsostek (Persero) Cabang Surabaya". Jurnal Ilmu Ekonomi \& Manajemen. Untag Surabaya.

Fitrianasari, Dini, Umar Nimran, Hamidah Nayati Utami. (2013). "Pengaruh Kompensasi Dan Kepuasan Kerja Terhadap Organizational Citizenship Behavior (Ocb) Dan Kinerja Karyawan”. Jurnal Profit. Universitas Brawijaya Malang.

Rohkman, Wahibur. (2011). "Organizational Justice As A Mediator For Transformational Leadership And Work Outcomes". Jurnal siasat bisnis. STAIN Kudus.

Bernard M. Bass. (1995). "THEORY OF TRANSFORMATIONAL

LEADERSHIP REDUX".

LEADERSHIP QUARTERLY. State University of New York at Binghamton. 